DOI: $10.30821 /$ miqot.v44i2.725

\title{
CONTESTING THE AUTHENTICITY OF THE HADITH SANAD: An Analysis of Leone Caetani's Thought
}

\author{
Muhammad \\ Universitas Islam Negeri Maulana Malik Ibrahim \\ Jl. Gajayana No 50 Dinoyo Lowokwaru Malang, 65144 \\ e-mail: muhammadlc@syariah.uin-malang.ac.id
}

\begin{abstract}
One of the most heated debate on the Prophet Traditions criticism is the issue of concerning the chain of transmitter or what is popularly known as sanad which consequently determine the validity of a hadith of the Prophet Muhammad. Even Muslim scholars consider sanad to be part of the religion of Islam. In contrast to this stand, Leone Caetani, one of the Italian orientalists who is famous for his historical works on Islam, tried to blatantly criticize the chain of transmitters of the hadith as well as review them in an approach and method he himself promoted. This paper attempts to explore L. Caetani's thoughts about the chain of transmitter of the Prophetic Traditions by applying literature study and descriptive-analytic methods. The result of this research is that L. Caetani assumes that sanad is not an integral part of the teaching of Islam but Muslim scholars but rather an adoption from the Arab tradition. In addition, it also implies that the existence of sanad is only the image of the name of the Prophet Muhammad and his narrators, and the narrators of hadith are people who cannot be followed and do a lot of practice of falsification in his narrations.
\end{abstract}

\begin{abstract}
Abstrak: Sanad hadis merupakan salah satu rangkaian terpenting dalam membuktikan sahih dan tidaknya sebuah hadis Nabi Muhammad. Bahkan sarjana Muslim menganggap sanad merupakan bagian dari agama Islam. Hal ini berbeda dengan pandangan Leone Caetani salah satu orientalis Italia yang terkenal dengan karya sejarah tentang agama Islam. Ia berusaha mengkaji ulang tentang sanad hadis dan memberikan kritikan terhadap sanad yang dianggap penting oleh umat Islam. Untuk mengupas pemikiran L. Caetani tentang sanad hadis dalam artikel ini, penulis menggunakan metode studi pustaka dan deskriptif-analitik. Hasil dari penelitian ini ialah L. Caetani berasumsi bahwa sanad bukan ajaran agama Islam melainkan sarjana Muslim mengadopsi dari tradisi orang Arab, adanya sanad hanya pencitraan nama Nabi Muhammad dan para perawinya, dan para perawi hadis merupakan orangorang yang tidak bisa diteladani dan banyak melakukan pemalsuan dalam periwayatannya.
\end{abstract}

Keywords: Leone Caetani, orientalis, sanad, hadis 


\section{Introduction}

Leone Caetani (1869-1935 CE) was one of the orientalists who focused on studying Islamic thought from the point of view of history, development, and language. When looking at the hadith of the Prophet Muhammad, he has a different view from Muslims in general. He argued that the hadith of the Prophet Muhammad couldn't be the basis of Islamic law in formulating a problem, because he Qur'an has explained that it doesn't need the hadith of the Prophet Muhammad. Furthermore, L. Caetani assumed that the hadiths which attributed to the Prophet Muhammad today, were not from the words of the Prophet Muhammad, but they were made by immoral and deceitful people. ${ }^{1}$

L. Caetani assumed that the hadith Nabawi was dominated by uncredible narrators like Ibn 'Abbâs and Abu Hurairah. Curiosly, their narrations were widely adopted by muslims and believed to be the great rawi (tsiqah). ${ }^{2}$ L. Caetani's assumption is clearly contrary to the hadith scholars arguments, especially when discussing about al-Jarh wa al-Ta'dil which clearly explains that Ibn 'Abbâs and Abu Hurairah are credible narrators, because both are the Prophet's companions. Credibility of the Prophet's companions included Ibn 'Abbâs and Abu Hurairah are also described by Lailiyatun Nafisah, that the majority of scholars agreed that the whole of Prophet's companions are 'adl. The verses of the Qur'an and The Hadith of Prophet has explained the justice/'adl of the Prophet's companions. ${ }^{3}$ From L. Caetani's argument which is contrary to the views of the Moslems is anxious which is in the form how L. Caetani views the existence of the hadith sanad of the Prophet Muhammad? And how is L. Caetani's view on the credibility of the Prophet's companions who has narrated many traditions Prophet Muhammad?

The study of the orientalist argument regarding the basics of Islamic law becomes interesting after reviewing Muhammad Abû Syuhbah's statement about the development of studies in the discipline of the Qur'an. He explained that one of the development steps in the study of the Qur'anic knowledge was to explain arguments against the basics of Islamic law and to criticize them. Basically, the issue of the authenticity of the hadith sanad itself is still a matter of controversy among scholars of Islamic studies. Even Nur Kholis Hauqalah explained that the controversy over the authenticity of this hadith does not only occur between Muslims and non-Muslims, but also between Muslims. ${ }^{4}$

Discussing disciplines that are the focus of orientalist studies of the East, especially Islam and its civilization, as revealed by Aan Supian, among others, are the Qur'an, hadith,

${ }^{1}$ Leone Caetani, Annali Dell'Islam, Vol. I (Milano: Ulrico Hoepli, 1926), p. 50.

${ }^{2}$ Ibid., p. 53.

${ }^{3}$ Lailiyatun Nafisah and Moh. Muhtador, "Wacana Keadilan Sahabat dalam Pandangan Ulama Klasik dan Kontemporer," in Al-Quds: Jurnal Studi Alquran dan Hadis, Vol. 2, No. 2, 2018, p. 166.

${ }^{4}$ Nur Kholis Hauqolah, "Otentisitas Sunnah dan Kedudukannya dalam Legalitas Hukum Islam," in al-Ahkam, Vol. 24, No. 1, 2014, p. 48. 
Islamic history, fiqh, theology, philosophy, literature, and others. ${ }^{5}$ What makes the thinking of the orientalists logical, is due to the basis and foundation used and reinforced by logic that seems very beautiful and solid to the common people. In fact, if we examine again there are many weaknesses in the basis for the development of this argument. This can be seen when Alouis Sprenger and William Muir argued that the inclusion of the name of the Prophet Muhammad in the hadith is only to justify and cover up lies and virtues. Therefore, the narration from al-Bukhârî in his Hadith book must be completely rejected. ${ }^{6}$

Regarding the arguments of the orientalists against the fundamentals of Islam, it is not something strange, this is due to some orientalists when studying the east aims to destroy the belief of Muslims. In this case Kamaruddin alluded to in one of his articles, "at first the orientalist study was very broad, but after realizing that it was the power of Islam that was dangerous, with its two main sources, the orientalist also paid attention to the hadith besides the Qur'an."7

It is interesting to study the thinking of one of the orientalist figures named L. Caetani. He is one of the eastern thinkers who was used as a reference by the next generation, especially in the field of Islamic history. In addition, among orientalists, he was known as a figure who was very brave to assume that the Prophet's companions were immoral and did not deserve to be role models and liars. More than that, the discussion that focuses on the orientalist thought of L. Caetani specifically has not been found from previous research, although research on other orientalist figures has been widely discussed.

When viewed from previous research, the discussion of orientalist thinking, especially in the field of hadith, can be categorized as not a foreign discussion and many have discussed it, both from the thoughts of one particular orientalist figure such as Joseph Schahct, Ignaz Goldzhiher and those who research orientalist thinking in general. What is unique in this article, which makes it different from previous research is that there is not a single article that specifically explains L. Caetani's thoughts regarding the authenticity of the hadith of the Prophet Muhammad when viewed from his sanad. Basically there are articles that mention L. Caetani's name, but only in passing. As with the articles written by Kamaruddin, ${ }^{8}$

${ }^{5}$ Aan Supian, "Studi Hadis di Kalangan Orientalisme," in NUANSA: Jurnal Studi Islam dan Kemasyarakatan, Vol. 9, No. 1, 2016, p. 26.

${ }^{6}$ Hasan Suadi, "Menyoal Kritik Sanad Joseph Schahct," in Riwayat: Jurnal Studi Hadis, Vol. 2, No. 1, 2016, p. 91. See also, Idri, "Perspektif Orientalis Tentang Hadis Nabi: Telaah Kritis dan Implikasinya Terhadap Eksistensi dan Kehujjahannya," in al-Tahrir: Jurnal Pemikiran Islam, Vol. 11, No. 1, 2011, p. 202.

${ }^{7}$ Kamaruddin, "Kritik M. Mustafa Azami Terhadap Pemikiran Para Orientalis Tentang Hadis Rasulullah," in al-Tahrir: Jurnal Pemikiran Islam, Vol. 11, No. 1, 2011, p. 223.

${ }^{8}$ Ibid., p. 227. 
Arif Chasanul Muna, ${ }^{9}$ and Fahmi Riayadi. ${ }^{10}$ All these articles only explain that L. Caetani is an Italian orientalist who denies the existence of the hadith of the Prophet Muhammad as the basis of Islam, because the hadith of the Prophet Muhammad only appeared in the 2nd century Hijriah. Furthermore, L. Caetani's opinion and the concept of thinking have not been found in previous research.

Appearing on the surface of L. Caetani's argument regarding the authenticity of the hadith of the Prophet Muhammad if a review of his sanad and concept of thinking is something that is important to reexamine, seeing that he is one of the orientalist figures whose arguments were used as a reference by the orientalists of the following generation. Basically the name L. Caetani is not a foreign name when studying the hadith from a western perspective, Nur Kholis Hauqola in his article had listed the names of orientalists who focus on the field of hadith, among them: Alois Sprenger, Sir William Muir, Ignaz Goldziher, David Samuel Margoliouth, Leon Caetani, down to Harald Motzki. ${ }^{11}$ However, it is unfortunate that a thorough study of the argument has not been found. Therefore, this article seeks to express an argument and concept of thinking L. Caetani in the matter of authenticity of the hadith of the Prophet Muhammad.

\section{Methodology}

This article discusses L. Caetani's views on the hadiths of the Prophet Muhammad that are spread among Muslims to this day. In this research, the primary source used was L. Caetani's work (Annali Dell'Islam) which known very phenomenal and made him famous for his thoughts on Islamic history. This work was written in French and was translated into Turkish. The method used in this article is a library research, in which all data sources come from written data that have a relationship with the topics discussed. ${ }^{12}$ Therefore This article discusses the thoughts of characters, so the appropriate type of library research in this article is study of the thoughts of figures. Regarding this, Amri Hamzah explained, "An effort to explore the thoughts of certain figures who have phenomenal work." ${ }^{13}$ In order to achieve the desired results, this article uses a descriptive-analytic analysis method. The purpose of this article is to explain L. Caetani's argument, without giving criticism to

${ }^{9}$ Arif Chasanul Muna, "Pola Pemalsuan Sanad dalam Periwayatan Hadis: Pandangan Muhaddisun dan Orientalis," in Jurnal Penelitian, Vol. 9, No. 1, 2012, p. 118.

${ }^{10}$ Fahmi Riyadi, "Asal Usul Hadis: Telaah Keakuratan Kritik M. Musòtòafâ A'zòamî atas Teori Isnâd Joseph Shacht" (Ph.D. Dissertation, UIN Sunan Kalijaga, 2016), p. 3.

${ }^{11}$ Hauqolah, Otentisitas Sunnah, p. 57.

${ }^{12}$ Muhammad, "Argumen Polemik atas Autentisitas Teks al-Qur'an" (Ph.D. Dissertation, UIN Sunan Ampel Surabaya, 2019), p. 23.

${ }^{13}$ Amri Hamzah, Penelitian Kepustakaan Library Research (Malang: Literasi Nusantara, 2020), p. 24. 
his argument, because L. Caetani's thoughts have not been thoroughly explored. Thus, the aim of this article is to surface the thoughts of L. Caetani.

\section{Results and Discussion}

\section{Biography of Leone Caetani the Orientalist}

L. Caetani A.K.A Prince Caetani was the one of the orientalists who spent his life in studying Islam. He was born in Rome, Italy in 1869 CE. He has spent his time studying in his country (Italy). He had a family of state officials, and it's recorded in history that he had been Foreign Minister in the American region. ${ }^{14}$

L. Caetani's interest in studying Islamic and eastern thought has led him to master foreign languages such as Arabic, Turkish, German, English and Persian. ${ }^{15}$ He has traveled between 1888 and 1894 to the Mediterranean countries of Africa and Asia. He is known as the one of protagonists of turning points in orientalist historiography, he has promoted studies that pay more attention ti the original characteristics of the Islamic empire than ideological and religious controversies. In this sense, the design of the analytic work of the Muluk Dynasty, which is dedicated to Islamic history is very mature. He was a member of Lincei's correspondent in 1911 and a national member since 1919. He participated as a volunteer in the First World War.

In 1927 he decided to move to Canada with his new partner and daughter, Sveva. Before expats, in order to preserve the valuable scientific and cultural heritage he had accumulated since 1924 he promoted the establishment, at the Accademia dei Lincei, of the "Caetani Foundation for Muslim Studies." In Vernon, Canada, after selling his estate in Italy, he bought a ranch, to spend the last decades of his life in solitary meditation and to spend his time mainly in rural activities, as he said in a famous letter to his friend Giorgio Levi Della Vida. Finally, in 1935 he died. ${ }^{16}$

Besides being an activist in Islamic studies, L. Caetani has also written many books and scientific works, although not all of his writings can be enjoyed at this time. Among the famous writings of L. Caetani include: 1) Chronographia Islamica (IV, Rome 1912). This book explains a lot about the vast chronology of Islam. 2) Studi di Storia Orientale (I, Milano 1911; III, Milano 1914). The book is planned in four volumes. The discussion in this book is about Islam and Christianity, pre-Islamic Arabs and Arabs, the Prophet Muhammad as the figure of the prophet and statesman. The beginning of the caliphate

14 "Leone Caetani," in http://www.treccani.it. Accessed March 2020.

${ }^{15}$ Mahmud H. Sakiroglu, "Ilk devir Islâm tarihi uzerine çalismalariyla taninan Italyan Sarkiyatçisi," in TDV Islamic Encyclopedia, Vol. 6, No. t, 1992, p. 545.

16 "Leone Caetani," in http://www.lincei-celebrazioni.it/ileoni_caetani.html. Accessed March 2020. 
and the conquest of Arabia I and III. 3) Onomasticon Arabicum (I-II, Rome 1915). In this work, he was assisted by Giuseppe Gabrieli. Described in this work the information on the names of people and places mentioned in historical, geographic and biographical studies related to Islam. 4) Annali dell'Islam. Between 1905 and 1926, this work was published in Milan and Rome in ten volumes. This 4th book describes the life of the Prophet and up to the age of 40. This work is the most famous and most productive work of L. Caetani and was printed offset in 1972-1973. 5) La Arabia nella storia del mondo (Romans: 1907). 6) La psicologia delle grandi vittorie arabe (Romans: 1907). 7) La Studio storico dell'Islam (Rome: 1908). 8) Maometto profeta d'Arabia (Rome: 1910). 9) Funzione dell'Islam nell 'Evoluzione della Civiltá (Rome: 1912). ${ }^{17}$

\section{The Controversy of Muslim Intellectuals against Leone Caetani's Work}

Although L. Caetani has many of the works that were used as a source of reference in the orientalist field by the next generations, however, he still received criticism in his scientific field. This is because L. Caetani didn't pay enough attention in the field of literature which is the field he worked on while studying. ${ }^{18}$ Apart from comments that criticize L. Caetani's thoughts which are not in line with the art field, other comments have emerged regarding the works that have been written by L. Caetani by modern Muslim intellectuals. Comments of the Muslim intellectuals cannot be separated from the pros and cons.

Fathiyah al-Nabrâwî in one of his articles explains that the works written by L. Caetani are great works, because L. Caetani tried to straighten out the views of other orientalists whenscramble the history of the Prophet Muhammad. ${ }^{19}$ Fâuq 'Umar Fawzî commented, "the work written by the orientalist L. Caetani is a work that is full of benefits because it is based on Islamic sources, many conformities with the prophet's historical story, and there are many truths in his work." ${ }^{20}$ Muhammad Lutfi Jum'ah commented, "for me, some orientalists like L. Caetani and others have adopted the critical method which is inversely related to the Islamic scholars. With their critical method, the orientalists of Islamic scholars can believe in the Prophet Muhammad and confirm that the Prophet Muhammad is a figure of revelation." 21

${ }^{17}$ F. Gabrieli, Leone Caetani, Storia e civiltà musulmana (Naples: tp 1947), p. 301-305. See also, Sakiroglu, Ilk Devir Islam Tarihi, p. 545.

${ }^{18}$ Sakiroglu, Ilk Devir Islam Tarihi, p. 545.

${ }^{19}$ Fathyes' 'Abd al-Fattâh al-Nabrâwî, "al-Mustasyriqûn wa al-Sîrah al-Nabawiyah," al-Maniyâ University, Proceeding at Mu'tamar al-Dawulî al-Mustasyriqûn wa al-Dirâsât al-'Arabiyah wa alIslâmiyah 4-6, Vol. I (Safar, 1427), p. 304.

${ }^{20}$ Fâruq Fawzî ‘Umar, al-Istisyrâq wa al-Târîkh al-Islâmî (Oman: Maktabah al-Ahliyah, 1998), p. 56.

${ }^{21}$ Muhammad Luthfî Jum'ah, "al-Sayyid Ridhâ wa al-Mustasyriqûn," in Majjalah al-Azhar, Vol. 3, No. 3, n.d, p. 242. 
'Abd al-Rahmân al-Badawî argues regarding L. Caetani's work, "in the works written by L. Caetani there are many wrong analyzes when discussing the issue of Islamic history. L. Caetani when talking about Islamic history does not have a strong foundation. Is an imaginary concept used by L. Caetani when discussing Islamic history. This can be proven when L. Caetani states that Muslim historians are considered as people who do not tell historical reality. He considers Muslim historians to be inconsistent when discussing Islamic history, blind and illogical in his arguments. Therefore, I dare to say that L. Caetani was an orientalist who included many falsehoods and khurafat in Islamic history." Furthermore al-Badhawî emphasized, "There are four foundations of L. Caetani in thinking about Islamic history, namely: critical methods that are overdosed, political, economic, and geographic perspectives, but forget to look at their religious aspects." 22

'Imâd al-Dîn Khalîl explained, "L. Caetani is an Italian orientalist who is famous for writing the history of the life of the Prophet Muhammad. In his works on history, he often uses wrong methods and concepts, because he prioritizes thinking and then strengthens it from the point of view of historical reality. Historical reality is used only as a reinforcement of the assumption of thinking, not thoughts that follow historical reality. He used all means to strengthen his thinking and was blind to Muslim historians." ${ }^{23}$ More than that, "Abd al'Azhîm al-Dîb in his work entitled al-Manhaj fî Kitâbât al-Gharbiyîn after examining L. Caetani's thoughts concluded that this Italian orientalist was a figure who denied the universality of Islamic teachings brought by the Prophet Muhammad. Thus, how can an orientalist like L. Caetani be recognized as true by Muslim intellectuals? ${ }^{24}$

The pros and cons of the work of L. Caetani from the Muslim intellectuals above, it is important to explain beforehand to consider the arguments raised by L. Caetani in the matter of the hadith sanad of the Prophet Muhammad. The discussion on the issue of the hadith of the Prophet Muhammad cannot be separated from L. Caetani's point of view when discussing the Islamic history of each of his works. By presenting Muslim intellectual views, it can be taken a middle ground that not all of L. Caetani's arguments are wrong and not all of his arguments are correct. Filtering and readjusting the literature of Islamic scholars as the main basis for absorbing L. Caetani's argument. Thus, objectivity in the scientific world is growing.

22 'Abd al-Raḩmân al-Badawâ, Difâ 'an Muhammad Dhid al-Muntaqishîn min Qadrih (Bairût: Dâr al-'Âlamiyah li al-Kutub wa al-Nasyr, n.d), p. 92.

23 'Imâd al-Dîn Khalîl, al-Mustasyriqûn wa al-Sîrah al-Nabawiyah, Vol. I (Riyâdh: Dâr alHadîts, 1405), p. 167.

24 'Abd al-'Azhîm al-Dîb, al-Manhaj fỉ Kitâbât al-Gharbiyîn 'an al-Târîkh al-Islâmî (Qatar: Kitâb al-Ummah, 1411), p. 115. 


\section{Leone Caetani's Perspective on Chains of Hadis Transmission}

Starting from a moment of admiration for the Prophet Muhammad, L. Caetani began to want to study more deeply about the figure of the Prophet Muhammad. Because of his admiration, L. Caetani attempted to evaluate the Prophet Muhammad using the concept of a materialist-Marxist point of view. Reyazul Hasan also conveyed this explanation in one of his articles published in $1982 . .^{25}$ The emergence of a sense of admiration for the Prophet Muhammad, was caused by L. Caetani when studying Islam directly referred to sources from the east. This is as stated by Sa'd bin Mûsâ al-Mûsî in one of his articles published in 2012. ${ }^{26}$

Maxime Rodinson and Abdullah Aydinliin his article explains the origin of the concept of thinking L. Caetani, "L. Caetani, assisted by his colleagues, put together all the material that Arab historians have written, its sources, year after year, and event after event. Not just collecting, but they studied and narrated with different narratives, Islamic history is written with a critical analysis based on methodological skepticism." ${ }^{27}$

L. Caetani's views on the figure of the Prophet Muhammad are clearly stated in his work Annali dell'Islam. In his work, he describes the figure of the Prophet Muhammad who is full of ugliness and ugliness. All of his arguments are based on history and historical stories quoted from the companions of the Prophet or Muslim scholars. The emergence of L. Caetani's thoughts on the figure of the Prophet Muhammad did not arise from a vacuum, but was caused by his assumption that the Prophet Muhammad was the greatest enemy of Christianity. ${ }^{28}$

More than that, L. Caetani also believes that the Prophet Muhammad is a figure with no clear lineage, the emergence of the hadith of the Prophet Muhammad was a step taken by Muslims to uplift the dignity of the Prophet Muhammad, and Prophet Muhammad had the same extraordinary abilities as magic, even Prophet Muhammad according to L. Caetani was the most accomplished magician. ${ }^{29}$ This cannot be blamed because L. Caetani's concept of thinking is a Marxist-materialist.

In one of the articles explained that the materialist-Marxist concept is the concept that L. Caetani used for asks a very important question regarding the social coordinates

${ }^{25}$ Reyazul Hasan, "Prince Leone Caetani. A Great Italian Orientalist," in Muslim World Journal, Vol. 72, No. 3, 1982, p. 48.

${ }^{26}$ Sa'd bin Mûsâ al-Mûsî, "al-Amîr Caetani wa al-Sîrah al-Nabawiyah," in Majjalah alSyarî’ah wa al-Dirâsât al-Islâmiyah, Vol. 20, 2012, p. 16.

${ }^{27}$ Maxime Rodinson and Abdullah Aydinli, "Muhammed'le Ilgili Arastirmalarin Bilançosu," in Journal Ilahiyat, Vol. 12, 2015, p. 159.

${ }^{28}$ Bilal Ahmad, "Leone Caetani's Annali dell'Islam on Sirah of the Prophet Muhammad," in Islamic Studies Journal, Vol. 45, No. 4, 2015, p. 206.

${ }^{29}$ Caetani, Annali, p. 29. 
of the Muslim movement. ${ }^{30}$ By using this concept L. Caetani dared to assume that the Prophet Muhammad was not the owner of the divine message sent to all mankind ${ }^{31}$ Ultimately L. Caetani charged that all Muslim historians of the first period were scholars of hiding the truth. ${ }^{32}$ With this sentimental viewpoint, it is clear that L. Caetani's aim was to raise the theme of sanad criticism to find weaknesses in the hadith of the Prophet Muhammad.

Departing from the concept of thinking like this, $\mathrm{L}$. Caetani tried to provide an assessment of the hadith of the Prophet Muhammad. L. Caetani's argument regarding the hadith of the Prophet Muhammad can be mapped into three basic buildings, namely: 1) Sanad is not from the teachings of Islam, but the tradition of the Arabs. 2) Sanad in Islam aims to uplift the dignity of narrators. 3) Hadith narrators (from the time of friends to other hadith imams) were experts in lies and did a lot of forgery in their words. These three basic arguments form L. Caetani to think that the hadith of the Prophet Muhammad was not the word of the Prophet Muhammad himself, but the words of the next generation which deliberately relied on the Prophet Muhammad. More details about the three main arguments as follows:

First, sanad is not from the teachings of Islam, but the traditions of the Arab people. L. Caetani assumed that the sanad known to Muslims generally did not come from the teachings of Islam itself, but rather sanad is a tradition of the Arabs in delivering news. ${ }^{33}$ The assumption of L. Caetani is clearly contrary to the statement of the Islamic scholars who explain that the existence of sanad is one of the teachings of the Islamic religion as explained by Ibn Mubârak. ${ }^{34}$ Apart from that, regarding this sanad, Shufyân al-Tsawrî also explained, "sanad is a weapon for Muslims. Without weapons, then with what we can kill the enemy." Salâh al-Dîn Abû Sa'îd explained that sanad was a privilege that Allah gave to the people of the Prophet Muhammad. Furthermore, he explained that this sanad was not found in people before the Prophet Muhammad. ${ }^{35}$ In one of the articles written by Zulheldi, he concluded that sanad is a characteristic of the people Prophet Muhammad. ${ }^{36}$ Likewise, Abdullah Khalaf Al Hammad in one of his articles explained that sanad is a privilege that is only given to Muslims. This sanad was never owned by the people before

${ }^{30}$ Rodinson and Aydinli,Muhammed'le Ilgili, p. 164.

${ }^{31}$ Caetani, Annali, p. 30. Departing from Caetani's statement, Indonesian Muslim scientists in their articles explain that Caetani is an otientist who does not believe in the Koran. As the author has mentioned in the previous discussion.

${ }^{32}$ Sakiroglu, Ilk devir Islam tarihi, h. 545.

${ }^{33}$ Sakiroglu, "Leone Caetani," in Türkiye Diyanet Vakfi Islam Ansiklopedisi, Vol. VI (Ankara: TDV Yayýnlarý, 1992), p. 544.

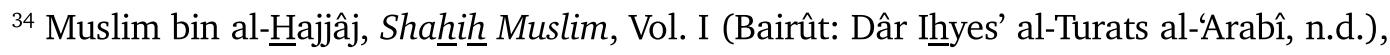
p. 77.

${ }^{35}$ Salâh al-Dîn Abû Sa'îd Khalîl bin Kaykaladi, Bughyah al-Multamis fî Subâ'yat Hadîts al-Imâm Mâlik bin Anas (Bairût: 'Alâm al-Kutub, 1985), p. 36.

${ }^{36}$ Zulheldi, "Eksistensi Sanad dalam Hadis," in MIQOT Jurnal Ilmu-ilmu Keislaman, Vol. 34, No. 2, 2010, p. 166. 
the people of Prophet Muhammad. ${ }^{37} \mathrm{~L}$. Caetani assumes that sanad is not from the teachings of Islam, not from his imagination, to strengthen his argument $\mathrm{L}$. Caetani provides evidence from a historical point of view. This is evidenced by his inclusion of narration using the sanad system during the time of Jahiliah. Among the evidences presented by him was a narration from Jawtsah who heard directly from Nawfel bin Mu'âwiyah. The history is as follows:

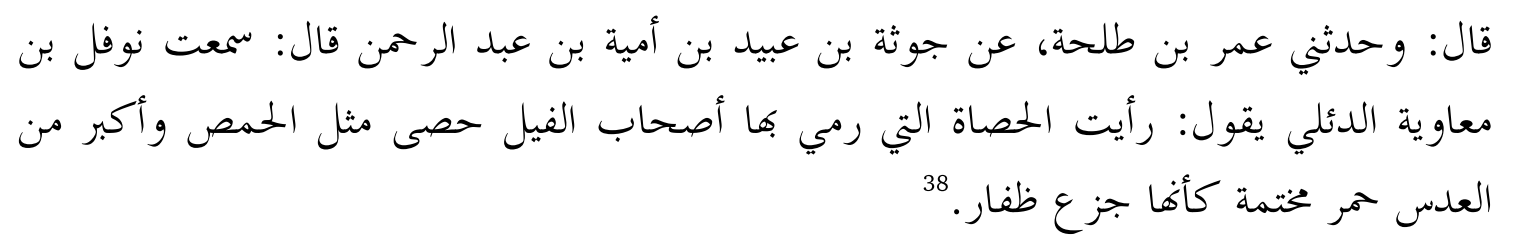

The history above according to L. Caentai explains the phenomenal story that happened on the day of the Prophet Muhammad's birth, namely the phenomenon of elephant soldiers attacking the Ka'bah. As we know, this phenomenon occurred before the Prophet Muhammad was sent. If sanad is part of the teachings of Islam or is a privilege that only Allah gave to the people of the Prophet Muhammad, then this story should have come without a series of sanad. In reality, this story comes with a sanad. Thus, the argument of Muslim scholars who claim that sanad is part of the teachings of Muslims and only given to the people of the Prophet Muhammad is a fatal mistake and is a lie. ${ }^{39}$

When traced back from the stories of the previous people, it is certain that L. Caetani's argument is proven true and real. The stories of the previous ummah which until now have been enjoyed by Muslims came accompanied by sanad, even in the issue of isrâiliyât which became the subject of controversy between Muslim intellectuals who also used sanad. If the story of the previous ummah comes with the existence of sanad, then it can be ascertained that sanad is not a feature that only the people of Prophet Muhammad have. But it is a tradition that goes way back before the Prophet Muhammad spread Islam. Therefore, it is not wrong if L. Caetani states that sanad is only a tradition that has been running in conveying news regarding the phenomenon that occurs, it is not the teaching of Islam.

In addition, to further strengthen his argument that sanad is an Arab tradition and not an Islamic teaching, he includes Arabic sairs which also use sanad in their delivery. One example proposed by L. Caetani is the sair of Abû Nuwwâs:

\footnotetext{
${ }^{37}$ Abdullah Khalaf al-Hammad, "Predication and its Importance in Islamic History Narration Criticism," in Research and Islamic Studies Journal, Vol. 0, No. 28, 2012, p. 95.

${ }^{38}$ Ahmad bin 'Abdullâh al-Ashbahânî, Dalâ'il al-Nubuwah li Abî Na'îm al-Ashbahânî (Bairût: Dâr al-Nafâis, 1986), p. 104.

${ }^{39}$ Caetani, Annali, Vol III, p. 139.
} 


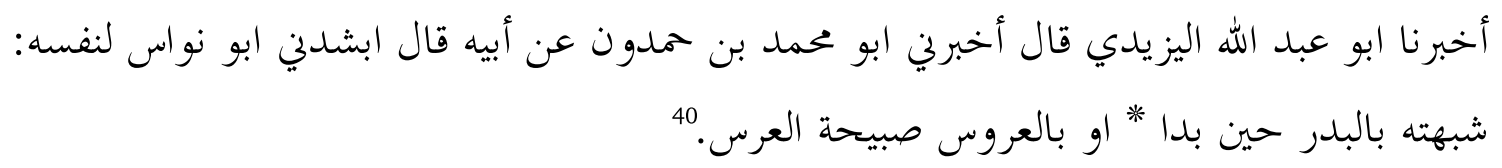

On the other hand, this sanad is also often used to trace the meaning of a word in an Arabic dictionary. This is often used in the book al-Fiq al-Lughah, one of the examples is as follows:

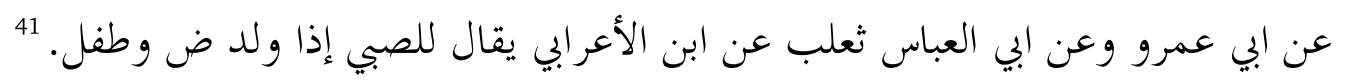

From these foundations L. Caetani has the view that sanad is not only a matter of religion or hadith of the Prophet Muhammad, but sanad is a tradition for Arabs when conveying a word that is heard from another person..$^{42}$ Thus, the Muslim intellectual argument that explains that sanad is an organ of religion is an inaccurate explanation and does not really understand the history of sanad itself. If sanad is part of Islam and is characteristic of Islamic teachings, it should not be used for stories, sair, and language terminology. However, in reality sanad can be used for anything that has nothing to do with religion. Thus, sanad cannot be said to be an organ of Islam as described by Muslim intellectuals when discussing the urgency of sanad in Islam.

On the other hand, if a flashback to the history of the emergence of sanad in the hadith of the Prophet Muhammad, it can be understood that originally sanad was not important in the narration of the hadith of the Prophet Muhammad. Companions and tabi'în do not need to mention a series of names of the nurses, but it is sufficient to convey "this explanation from the Prophet Muhammad." However, with the passage of time and the growing religion of Islam, the new Muslims needed sanad as reinforcing evidence that what was said to originate from the Prophet Muhammad. ${ }^{43}$ If sanad is a characteristic of Muslims and a privilege that only Allah gives to Muslims, then the hadith sanad should have been running since the time of Prophet Muhammad and his companions, not during the era of slander during the tabi'în period. In one of the Islamic literature, it is explained that the first person who tested the truth of sanad was 'Âmir al-Sya'bî (d. 104 H). ${ }^{44}$ Thus, p. 194.

40 'Abd al-Rahmân bin Ishâq al-Zajjâjî, al-Amâlî li al-Zajjâjî (Bairût: Dâr al-Ihyya', 1987),

${ }^{41}$ Muhammad bin Ismâîil al-Tsa'âlibî, Fiqh al-Lughah fî Asrâr al-'Arabiy (Bairût: Maktabah al-Mu'âshir, 2000), p. 133.

${ }^{42}$ Caetani, Annali, Vol. III, p. 143.

${ }^{43}$ Ahmad "Âyisy al-Badr, "Ahamiyah al-Isnâd wa Makânatuh wa Nasyatuh fî al-Islâm," in Huda al-Islâm: Wuzârah al-Awqâf wa al-Syu'ûn wa al-Muqaddasât al-Islâmiyah, Vol. 4, No. 50, 2006, p. 67.

${ }^{44}$ Ibid., 66. About this thing, Siti Fatimah explains in one of her articles, Joseph Schacht, who followed the founder L. Caetani explains that the practice of using sanad in religious teachings Islam is not older than the early second century of the second Hijri century. Siti Fatimah, "Sistem 
it can be said that sanad in the teachings of Islam is a new scientific discipline and before sanad developed in Islamic teachings, the Arabs first practiced this sanad.

Second, Sanad in Islam aims to uplift the dignity of narrators. L. Caetani thinks that the sanad applied in Islam is a step to image the good name of the nurses. L. Caetani explained after defining sanad, Thus, it is customary to convey an explanation of the explanation or actions of the Prophet Muhammad to others. This is done to protect the names of the people who convey the information. Thus, it can be assumed that the narrator's name came into effect when the Prophet died. ${ }^{45}$ Yusuf Zâhir Efendi also mentioned L. Caetani's statement in one of his articles. ${ }^{46}$

In simple terms from the viewpoint of L. Caetani above, the existence of sanad applied by Muslims is a step to elevate the image of the Prophet Muhammad, because with the sanad the name of the Prophet Muhammad is the main source. With many narrations whose main source is the Prophet Muhammad, the name of the Prophet Muhammad has become increasingly popular. Not only was the name of the Prophet Muhammad popular, but other names that were lined up in the order of the sanad also became popular. Therefore, it is not surprising that the names of al-Bukhârî, Muslim, and other hadith imams are well known among Muslims, because these names participate in the narration of the hadith so that their names are taken up by themselves. According to L. Caetani, all of this was done for the sake of brand name. This can be understood from L. Caetani's expression, "the name of the narrator came into effect when the Prophet died."

In Islamic literature itself explains that basically the companions never doubted each other after the death of the Prophet Muhammad. The tabi'in also never doubted each other. However, this changed after there was a lot of slander among the tabi'in. From here on, the tabi'in demanded sanad. More than that, Muhammad Ali in his article explained that after including Ibn Sîrîn's opinion,"In dealing with a hadith, it is very important to first investigate the narrators involved in the hadith's sanad. ${ }^{47}$ From this argument, L. Caetani strengthens his argument that the beginning of sanad in Islam is not that important, but after slander occurs among Muslims, sanad becomes something that is inseparable

Isnad dan Otentisitas Hadits: Kajian Orientalis dan Gugatan Atasnya," in Jurnal Ulul Albab, Vol. 15, No. 2, 2014, p. 213. See also Mhd. Syahnan, Contemporary Islamic Legal Discourse: A Study of Sayyid Quthb's Fi Zhilal al-Qur'an (Medan: IAIN Press, 2010), especially Chapter One; Hukum Islam dalam Bingkai Transdisipliner (Medan: Perdana Publishing, 2018).

${ }^{45}$ Caetani, Annali, Vol. I, p. 29-30.

${ }^{46}$ Yusuf Zâhir Efendi, "Islâm Tarihinde Isnâd," in Jurnal Istem, Vol. 17, No. 34, 2019, p. 511.

${ }^{47}$ Muhammad 'Ali, "Sejarah dan Kedudukan Sanad dalam Hadis Nabi," in Tahdis: Jurnal Kajian Ilmu al-Hadis, Vol. 7, No. 1, 2016, p. 57. For information on the convergence of Prophetic Traditions and Islamic legal formation, see Mhd. Syahnan, "The Image of the Prophet and the Systematization of Ushul al-Fiqh: A Study of al-Shafi'i's Risalah," in MIQOT: Jurnal Ilmu-ilmu Keislaman, No. 103, 1998, p. 44-50. 
from the narration of the hadith. With this, Muslims are more concerned with sanad, and do not consider it important to the hadith editorial itself. ${ }^{48}$

If we re-analyze the assumptions of Muslim scholars, it strongly supports the ideas of L. Caetani in his Annali Dell'slam, because the statement 'researching narrators involved in sanad' indicates that these names have become known as a connector of hadiths like Abû Hurairah, Ibn 'Abbâs, Bukhârî, and Muslim. Basically, these names are known as hadith narrators, because the number of mentions of names is not based on the truth of the hadith that was narrated itself. Because these names are famous, their narrations have been well received by Muslims. This is what is meant by the image of the name and his name has been sold since the death of the Prophet Muhammad by L. Caetani.

Third, the narrators of hadith are experts in lies and do a lot of forgery in their words. In this section L. Caetani assumes that the narrators of hadith are immoral and not exemplary people. He examined one by one the hadith narrators from the time of the companions to the next generation of narrators. ${ }^{49}$ Not free from the view of his sentiment towards the hadith sanad, he also criticized the leaders of the hadith narrators. Among the narrators of the hadith he criticized were two friendly figures who received special attention, namely Abû Hurairah and Ibn.'Abbâs. Even L. Caetani was of the opinion that these two figures of the Prophet's companions had the most lying and forgery. ${ }^{50}$ Meanwhile, among the imams who received severe criticism was al-Bukhârî.

Regarding Abû Hurairah, L. Caetani assumed that there was a ridiculous explanation for the figure of Abû Hurairah. Abû Hurairah felt that he listened to the explanation of the Prophet Muhammad more than the Prophet's wife and other companions. There was even a debate between Abû Hurairah and 'Âisyah. Abû Hurairah was not ashamed to say that he was with the Prophet Muhammad more often than the Prophet Muhammad's wife. ${ }^{51}$ This story can be seen below:

$$
\begin{aligned}
& \text { لما قالت له عائشة: إنك لتحدث حديثاً ما سمعته من النبي صلى الله عليه وسلم، أجابها بجواب لا } \\
& \text { أدب فيه ولا وقار إذ قال لها... شغلك عنه صلى الله عليه وسلم المرآة والمكحلة. وفي رواية: ما } \\
& \text { كانت تشغلني عنه المكحلة والخضاب ، ولكن أرى ذلك شغلك. } 52
\end{aligned}
$$

According to L. Caetani, the story above is very illogical and it seems that Abû Hurairah was a liar, because how could Abû Hurairah think he was more with the Prophet

${ }^{48}$ Caetani, Annali, Vol. I, p. 35-36.

${ }^{49}$ Ibid., p. 53.

${ }^{50}$ Ibid., p. 53.

${ }^{51}$ Ibid., p. 54.

${ }^{52}$ 'Abd al-Rahmân bin Yahyâ al-Ma'lamî, Anwâr al-Kâsyifah limâ fí Kitâb Adhwâ' 'alâ al-Sunnah min al-Zalal wa al-Tadhlîl wa al-Mujâzafah, Vol. I (Bairût: 'Âlam al-Kutub, n.d.), p. 177. 
than the Prophet's wife? On the other hand, L. Caetani also saw from the historical evidence that Abû Hurairah embraced Islam later than other friendly rulers such as Abû Bakr, 'Umar, 'Alî bin Abî Thâlib, and others. ${ }^{53}$ Regarding L. Caetani's argument, it is indisputable, because in Islamic history it is clear that Abû Hurairah entered Islam and lived with the Prophet for only a period of one year and a few months. When logged into it, how could a person narrates more from the Prophet than other companions, while the time with the Prophet was only one year and a few months? ${ }^{54}$

When viewed from the hadiths listed in the book Shahîh $\underline{h}$ al-Bukhârî, then it can be found that al-Bukhârî Many took the hadith narrated by Abû Hurairah compared to the other companions who converted to Islam earlier. It is recorded that the hadith narrated

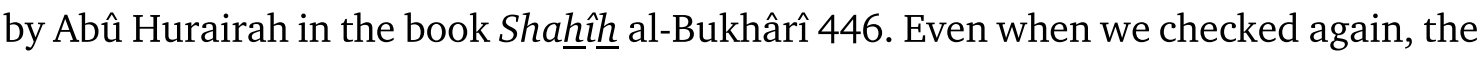
number of hadiths originating from Abairah Hurairah was approximately $5375 .{ }^{55}$ The narrative of Abû Hurairah that is quoted by al-Bukhârî is far from the narrative of other official friends, as Abû Bakr only narrated 104 and only 22 hadiths were included in the book of al-Bukhârî. ${ }^{56}$ Whereas Abû Bakr with the Prophet was approximately 23 years old. Furthermore, L. Caetani also explained the story of 'Umar bin al-Khaththâb's anger towards Abû Hurairah because he talked too much about the Prophet's hadith, even 'Umar had time to whip him. ${ }^{57}$ The prohibition of 'Umar bin al-Khaththâb to Abû Hurairah regarding the number of narrations in this hadith was also explained by Arofatul Mu'awanah, but Mu'awanah's explanation seemed very imposing when looking at 'Umar's attitude. He explained that the steps chosen by 'Umar were one of the elements to preserve the hadith of the Prophet Muhammad. ${ }^{58}$

The author argues that Mu'awanah's analysis is too self-imposed, because there is a statement in order to preserve the hadith, so it is prohibited to discuss the hadith. If we re-analyze it, if indeed 'Umar tried to preserve the hadith, then the step chosen should not be a prohibition in discussing hadith, but could be done in other ways such as writing or other. If the hadith is not discussed, then automatically the hadith can be forgotten. This must have other elements that caused 'Umar to forbid Abû Hurairah to discuss the hadith and why was Abû Hurairah flogged? Whereas it is clear, according to the views of the hadith reviewers, Abû Hurairah is a fair and trustworthy person. Thus, it is not wrong if L. Caetani thinks that Abû Hurairah in his narration still needs to be questioned again. Ab Rayyah's criticism of Abû Hurairah was also mentioned by Ab pendapat Rayyah,

${ }^{53}$ Caetani, Annali, Vol. I, p. 54.

${ }^{54}$ Ibid., p. 50-51.

${ }^{55}$ Mahmûd Abû Rayyah, Abû Hurairah (Bairût: Mu'asasah al-A'lamî, 1993), p. 135.

56 'Abd al-Rahmân bin Abû Bakar al-Suyûthî, Târîkh al-Khulafâ (Egyptian: Mathba'ah alSa'âdah, 1952), p. 79.

${ }^{57}$ Caetani, Annali, p. 55.

${ }^{58}$ Arofatul Mu'awanah, "Perkembangan Hadis Pada Masa Sahabat: Taqlîl wa Tathabut min al-Riwâh," in Jurnal Kaca, Vol. 9, No. 2, 2019, p. 17. 
although he received a positive response, Abû Rayyah's opinion received a negative response from other Muslim intellectual circles. Even Abû Rayyah is claimed to be a figure whose thoughts were influenced by Orientalist thinking. This is as conveyed by Abû Syuhbah in his work Difâ' 'an al-Sunnah. ${ }^{59}$

Not only did Abû Hurairah get the sentimental views of L. Caetani, but Ibn 'Abbâs did not escape his criticism. L. Caetani assumed that the narrations which emerged from Ibn 'Abbâs were only Ibn's fairy tales and narrations 'Abbâs is his personal conjecture not based on the words of the Prophet. ${ }^{60}$ Until finally L. Caetani raised a question, "how could the other friends narrate less than the two juniors (Abû Hurairah and Ibn 'Abbâs?) Whereas the one who was known to be the most honest and loyal to the Prophet was the generation of his seniors." ${ }^{61}$ In the perspective of L. Caetani, Ibn 'Abbâs is a figure who does not need to be respected. Ibn 'Abbâs only made use of the elements of the lineage, so that all of his words could be accepted by the Arab community at that time. This observes that 'Abbâs bin Abd al-Muthalib is the uncle of the Prophet Muhammad. Furthermore, L. Caetani argued that Ibn 'Abbâs chose to talk a lot about hadith as a step for worldly affairs, not just to uphold Islam itself. ${ }^{62}$

L. Caetani's assumption regarding Ibn 'Abbâs departs from a historical approach. He made logic at the death of the Prophet Muhammad, Ibn 'Abbâs still at a very young age. In the literature there are two versions regarding Ibn 'Abbâs when the Prophet Muhammad died. Some argue at that time Ibn Abbâs 10 years ${ }^{63}$ and there is also an opinion that he is 13 years old. ${ }^{64}$ L. Caetani admits the truth of the history of Imam Muslim which explains that Ibn 'Abbâs is a smart figure. With his intelligence, Ibn 'Abbâs could observe the Prophet Muhammad's behavior while living with the Prophet. With intelligence in observation, Ibn 'Abbâs dare to rely on his words directly on the Prophet Muhammad, even though these words actually did not come from the Prophet Muhammad ${ }^{65}$ When analyzed, it is impossible, children who are still in their teens can transmit more traditions than those who are older. Using this analysis of age and intelligence led L. Caetani to argue Ibn 'Abbâs is a figure who has done a lot of forgery and lies in narration whose goal is nothing but worldly affairs. ${ }^{66}$

${ }^{59}$ Muhammad bin Muhammad Abû Syuhbab, Difâ' 'an al-Sunnah wa Radd Syubah alMustasyriqîn wa al-Kuttâb al-Mu'âshirîn wa Bayân al-Syubah al-Wâridah 'alâ al-Sunnah Qadîman wa Hadîtsan (Cairo: Maktabah al-Sunnah, 1989), p. 38.

${ }^{60}$ Caetani, Annali, p. 54.

${ }^{61}$ Ibid., p. 41. See also, Bilal Ahmad, Leone Caetani's, p. 209.

${ }^{62}$ Ibid., p. 48.

${ }^{63}$ Ibrâhîm bin Ahmad, Mukhtashar Târîkh Dimasyq li Ibn 'Asâkir, Vol. IV (Bairût: Dâr alFikr, 1987), p. 234.

${ }^{64}$ 'Izzuddin bin al-Atsîr, Usd al-Ghâbah fĩ Ma'rifah al-Shahabah, Vol. I (Bairût: Dâr al-Fikr, 1989), p. 630.

${ }^{65}$ Caetani, Annali, Vol. I, p. 51.

${ }^{66}$ Ibid., Vol II, p. 121. See also, M. Asim Köksal, Caetani'ye Raddiye: Italyan Müstesrik Leone 
Bahar Lacin in his dissertation responds to L. Caetani's argument regarding Ibn 'Abbâs many narrated hadith only for worldly affairs. Lacin explained that the argument put forward by L. Caetani was limited to presumption which did not have a strong and accurate basis. L. Caetani only wanted to provoke slander on Ibn 'Abbâs and tried to eliminate the Muslim faith in Ibn Abbâs. ${ }^{67}$ Basically slander against Ibn Abbâs as a figure who narrated many hadiths was a natural thing for the orientalists before L. Caetani. Ignaz Goldziher as an example, he explained that Ibn 'Abbâs in his narration cannot be accepted. This is due, Ibn 'Abbâs took history from the Jews. ${ }^{68}$

Continuing with L. Caetani's criticism of the hadith imams, he thought that alBukhârî and Muslims were not objective in approaching the hadiths they included in his work. It can be seen that al-Bukhârî and Muslims narrated many traditions that came from Abû Hurairah and Ibn 'Abbâs. In fact, the two best friends had clear weaknesses, committed many forgery and lies in their accounts. It was impressed that al-Bukhârî and Muslims turned a deaf ear to the comments of the other princes of Abu Hurairah and Ibn 'Abbâs. This is the objectivity of the hadith imams known to Muslims as the most true books after the Qur'an. ${ }^{69}$

The quotation of al-Bukhârî and Muslim from the junior friend figures above, it is clear that al-Bukhârî and Muslim are classified as experts in lying and cannot be trusted in their narrations. This examines the sources taken by the two hadith imams from people whose weaknesses are clearly visible and have the potential to commit forgery and lies.

\section{Conclusion}

From the above review, it can be concluded that L. Caetani is an Italian orientalist who pursues Islamic studies, especially in the field of Islamic history. From this knowledge of Islamic history, L. Caetani developed his thoughts to research the hadith sanad. He thought that the sanad used in the hadith of the Prophet Muhammad was notbagian from Muslims but the result of the adoption of the Arab traditions of Jahiliah. In addition, the existence of the sanad used in the hadith is only limited to imaging the good name of the narrator, so that knownaudiences and finally L. Caetani assumed that the narrators

Caetani'nin Yazdigi Islam Tarihi'ndeki Isnat ve Iftiralara Cevap, Vol. I (Istanbul: Iz Yayinevleri, 2015), p. 201.

${ }^{67}$ Bahar Lacin, “Caetani'nin Annali dell'Islam Adli Kitabi Cercevesinde HZ. Peygamber ve Hadith Hakkindaki" (Ph.D. Dissertation, Marmara Universitersi, 2019), p.45.

${ }^{68}$ Ayis Mukholik, "Herbert Berg and the Orientalist Verification of Hadith in the Tafsîr Jami 'al-Bayan fi Tafsîr al-Qur'an," in Millati: Journal of Islamic Studies and Humanities, Vol. 2, No. 1, 2017, p. 29. See also, Ahmad Khoirur Rozikin, "Critical Analysis of the Issue Negative Abu Hurairah and Ibn Abbâs in Israiliyyat," in Al-Bayan: Jurnal Ilmu al-Qur'an dan Hadist, Vol. 1, No. 1, 2018, p. 39.

${ }^{69}$ Caetani, Annali, Vol. I, p. 40. See also, Lacin, Caetani'nin Annali Dell'Islam, p. 78. 
of the hadith were deceitful and immoral as well as Abû Hurairah and Ibn 'Abbâs. Even though these two figures are figures who have narrated many hadiths Prophet Muhammad. As previously explained, this article discusses arguments L. Caetani regarding the hadith of the Prophet Muhammad without being accompanied by any criticism of the arguments constructed by L. Caetani. This step was chosen by the author, because no research on the hadith perspective of $\mathrm{L}$. Caetani has not been discussed. Oleh because of this article focus on arguments of the Italian orientalist L. Caetani In the case of the hadith sanad, it is certain that the limitations in this article do not raise criticism against L. Caetani's argument. This limitation can be a recommendation for further researchers in concept thinking research L. Caetani in photographing the hadith of the Prophet Muhammad.

\section{References}

Abû Rayyah, Mahmûd. Abû Hurairah. Bairût: Mu'asasah al-A'lamî, 1993.

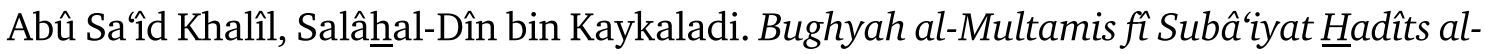
Imâm Mâlik bin Anas. Beirût: 'Alâm al-Kutub, 1985.

Abû Syuhbah, Muhammad bin Muhammad. al-Madkhal li Dirâsah al-Qur'ân al-Karîm. Riyâdh: Dâr al-Liwâ', 1987.

Ahmad, Bilal. "Leone Caetani's Annali dell'Islam on Sirah of the Prophet Muhammad," in Islamic Studies Journal, Vol. 45, No. 4, 2015.

Al-Ashbahânî, Ahmad bin 'Abdullah. Dalẩil al-Nubuwah li Abî Na îm al-Ashbahânî. Bairût: Dâr al-Nafâis, 1986.

Ali, Muhammad. "Sejarah dan Kedudukan Sanad dalam Hadis Nabi," in Tahdis: Jurnal Kajian Ilmu al-Hadis, Vol. 7, No. 1, 2016.

Al-Badâwî, 'Abd al-Rahmân. Difâ 'an Muhamammad Dhid al-Muntaqishîn min Qadrih. Bairût: Dâr al-'̂Alamiyah li al-Kutub wa al-Nasyr, n.d.

Al-Badr, Ahmad 'Ayisy. "Ahamiyah al-Isnâd wa Makânatuh wa Nasyatuh fî al-Islâm," in Huda al-Islâm: Wuzârah al-Awqâf wa al-Syu'ûn wa al-Muqaddasât al-Islâmiyah, Vol. 4, No. 50, 2006.

Caetani, Leone. Annali dell'Islam. Milano: Ulrico Hoepli, 1926.

Comitato Nazionale per Il iv Centenario della Fondazione della Accademia dei Lincei, "Leone Caetani," (14March 2011), in http://www.lincei-celebrazioni.it/ileoni_caetani.html

Al-Dîb, 'Abd al-'Azhîm. al-Manhaj fî Kitâbât al-Gharbiyîn 'an al-Târîkh al-Islâmî. Qatar: Kitâb al-Ummah, 1411.

Efendi, Yusuf Zâhir. "Islâm Tarihinde Isnâd," in the Istem Journal, Vol. 17, No. 34, 2019.

Fatimah, Siti. "Sistem Isnad dan Otentisitas Hadits: Kajian Orientalis dan Gugatan Atasnya," in Ulul Albab: Jurnal Studi Islam, Vol. 15, No. 2, 2014.

Gabriel, Francesco. "Leone Caetani” Storia e Civiltà Musulmana. Naples: 1947. 
Fatimah, Siti. "Dizionario Biografico Degli Italiani," Vol. 16, 1973, in http://www.treccani.it/ enciclopedia/leone-caetani_(Dizionario-Biografico).

Al Hammad, Abdullah Khalaf. "Predication and its Importance in Islamic History Narration Criticism," in Research and Islamic Studies Journal, Vol. 0, No. 28, 2012.

Hamza, Amri. Metode Penelitian Kepustakaan Library Research. Malang: Literasi Nusantara, 2020.

Hasan, Reyazul. "Prince Leone Caetani. A Great Italian Orientalist," in the Muslim World Journal, Vol. 72 No. 3, 1982.

Hauqolah, Nur Kholis. "Otentisitas Sunnah dan Kedudukannya dalam Legalitas Hukum Islam," in Jurnal al-Ahkam, Vol. 24 No. 1, 2014.

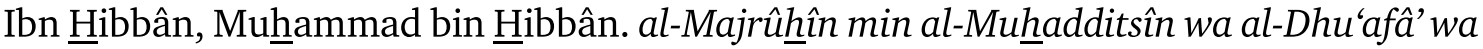
al-Matrukîn. Bairût: Dâr al-Ma'rifah, 1992.

Ibrâhîm bin Aḥmad. Mukhtashar Târîkh Dimasyq li Ibn 'Asâkir. Bairût: Dâr al-Fikr, 1987.

Idri. "Perspektif Orientalis Tentang Hadis Nabi: Telaah Kritis dan Implikasinya Terhadap Eksistensi dan Kehujjahannya," in Jurnal al-Tahrir: Jurnal Pemikiran Islam, Vol. 11, No. 1, 2011.

'Izzuddin bin al-Atsîr. Usd al-Ghâbah fî Ma'rifah al-Shahâhbah. Bairût: Dâr al-Fikr, 1989.

Jum‘ah, Muhammad Luthfi. "Al-Sayyid Ridhâ wa al-Mustasyriqûn," in Majjalah al-Azhâr. Vol. 3, No. 3. n.d

Khalîl, 'Imâd al-Dîn. al-Mustasyriqûn wa al-Sîrah al-Nabawiyah. Riyâdh: Dâr al-Hadîts, 1405.

Kamaruddin. "Kritik M. Mustafa Azami Terhadap Pemikiran Para Orientalis Tentang Hadis Rasulullah," in Jurnal al-Tahrir: Jurnal Pemikiran Islam, Vol. 11 No. 1, 2011.

Köksal, M. Asim. Caetani'ye Raddiye:Italyan Müstesrik Leone Caetani’nin Yazdigi Islam Tarihindeki Isnat ve Iftiralara Cevap. Istanbul: Iz Yayinevleri, 2015.

Lacin, Bahar. “Caetani'nin Annali dell'Islam Adli Kitabi Cercevesinde HZ. Peygamber ve Hadith Hakkindaki.” Ph.D. Dissertation, Marmara Universitersi, 2019.

Al-Ma'lamî, Abd al-Raḩman bin Yeshyes. Anwâr al-Kâsyifah limâ fî Kitâb Adhwâ' 'alâ alSunnah min al-Zalal wa al-Tadhlîl wa al-Mujâzafah. Bairût: 'Âlam al-Kutub, n.d.

Rodinson, Maxime and Abdullah Aydinli. "Muhammed'le Ilgili Arastirmalarin Bilançosu," in Journal Ilahiyat, Vol. 12, No. t. 2015.

Mu'awanah, Arofatul. "Perkembangan Hadis Pada Masa Sahabat: Taqlîl wa Tathabut min al-Riwâh," in Jurnal Kaca Jurusan Ushuluddin STAI Al Fitrah, Vol. 9, No. 2, 2019.

Mukholik, Ayis. "Herbert Berg dan Verifikasi Orientalis Hadis dalam Kitab Tafsîr Jami' alBayan fi Tafsîr al-Qur'an," in Millati: Journal of Islamic Studies dan Humanities. Vol. 2, No. 1, 2017.

Muna, Arif Chasanul. "Pola Pemalsuan Sanad dalam Periwayatan Hadis: Pandangan Muhaddisun dan Orientalis," in Jurnal Penelitian, Vol. 9 No. 1, 2012. 
MIQOT Vol. 44 No. 2 July-December 2020

Muhammad. "Polemik Argumen Polemik atas Autentisitas Teks al-Qur'an." Ph.D. Dissertation, UIN Sunan Ampel Surabaya, 2019.

Al-Mûsî, Sa'd bin Mûsâ. "Al-Amîr Caetani wa al-Sîrah al-Nabawiyah," in Majjalah alSharî'ah wa al-Dirâsât al-Islâmiyah, Vol. 20 No. 0, 2012.

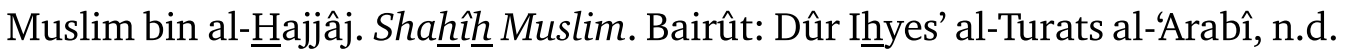

Al-Nabrâwî, Fathiyah 'Abd al-Fattâh. "al-Mustasyriqûn wa al-Sîrah al-Nabawiyah, alManiyâ University." Proceeding to Mu'tamar al-Dawulî al-Mustasyriqûn wa al-Dirâsât al-Arabiyah wa al-Islâmiyah 4-6, 1427.

Nafisah, Lailiyatun and Moh. Muhtador. "Wacana Keadilan Sahabat dalam Pandangan Ulama Klasik dan Kontemporer," in Al-Quds: Jurnal Studi AlQur'an dan Hadis, Vol. 2, No. 2, 2018.

Riyadi, Fahmi. "Asal Usul Hadis: Telaah Keakuratan Kritik M. Mustafâ A‘zamî atas Teori Isnâd Joseph Shacht." Ph.D. Dissertation, UIN Sunan Kalijaga, 2016.

Rozikin, Ahmad Khoirur. "Analisis Kritis Terhadap Isu Negatif Abu Hurairah dan Ibnu Abbâs dalam Israiliyyat," in Al-Bayan: Jurnal Ilmu al-Qur'an dan Hadist, Vol. 1, No. 1, 2018.

Sakiroglu, Mahmud H. "Ilk Devir Islâm Tarihi Üzerine Çalipmalariyla Taninan Italyan Sarkiyatçisi," in the TDV Islamic Encyclopedia. Vol. 6, No. 0, 1992.

Sakiroglu, Mahmud H. "Leone Caetani”, Türkiye Diyanet Vakfi Islam Ansiklopedisi. Ankara: TDV Yayýnlarý, 1992.

Suadi, Hasan. "Menyoal Kritik Sanad Joseph Schahct," in Riwayat: Jurnal Studi Hadis, Vol. 2 No. 1, 2016.

Supian, Aan. "Studi Hadis di Kalangan Orientalisme," in NUANSA: Jurnal Studi Islam dan Kemasyarakatan, Vol. 9 No. 1, 2016.

Al-Suyûthî, 'Abd al-Rahmân bin Abû Bakr. Târîkh al-Khulafâ. Egypt: Mathba'ah al-Sa'âdah, 1952.

Syahnan, Mhd. Contemporary Islamic Legal Discourse: A Study of Sayyid Quthb's fi Zhilal al-Qur'an. Medan: IAIN Press, 2010.

Syahnan, Mhd. Hukum Islam dalam Bingkai Transdisipliner. Medan: Perdana Publishing, 2018.

Syahnan, Mhd. "The Image of the Prophet and the Systematization of Ushul al-Fiqh: A Study of al-Shafi'i's Risalah," in MIQOT: Jurnal Ilmu-ilmu Keislaman, No. 103, 1998.

Al-Tsa'âlibî, Muhammad bin Isma'îl. Fiq al-Lughah fì Asrâr al-Arabiy. Bairût: Maktabah al-Mu'âshir, 2000.

'Umar, Fâruq Fawzî. al-Istisyrâq wa al-Târîkh al-Islâmî. Oman: Maktabah al-Ahliyah, 1998. Al-Zajjajî, 'Abd al-Rahmân bin Ishaqa. al-Amâlî li al-Zajjajî. Bairût: Dâr al-Ihya', 1987.

Zulheldi. "Eksistensi Sanad dalam Hadis," in MIQOT Jurnal Ilmu-ilmu Keislaman, Vol. 34 No. 2, 2010. 